\title{
STUDENTS' REFLECTIVE ABSTRACTION ABILITY ON LINEAR ALGEBRA PROBLEM SOLVING AND RELATIONSHIP WITH PREREQUISITE KNOWLEDGE
}

\author{
Rahayu Kariadinata \\ Universitas Islam Negeri Sunan Gunung Djati Bandung, Indonesia
}

\begin{tabular}{l} 
Article Info \\
\hline Article history: \\
Received Aug 3, 2020 \\
Revised Oct 18, 2020 \\
Accepted Nov 9, 2020 \\
\hline
\end{tabular}

\section{Keywords:}

Prerequisite Knowledge, Problem Solving, Reflective Abstraction

\begin{abstract}
This study aims to describe the achievement of the ability of students' reflective abstraction in solving Linear Algebra problems and the relationship with prerequisite knowledge. The important of this research because the characteristic of Linear Algebra requiring reflectif abstraction skill that must be support by the prerequisite knowledge. The reflective abstraction abilities studied in this study are level, i.e.1) recognition,2) representation, 3) structural abstraction, and 4) structural awareness. These stages are adjusted to Polya's problem solving stages, namely: understanding the problem, devising a plan, carrying out the plan, and looking back. This type of research is descriptivequantitative. The subjects of this study were students of the Mathematics Education Study Program, Faculty of Tarbiyah and Teacher Training of UIN Sunan Gunung Djati Bandung Indonesia. Collecting data through tests and interviews, data were analyzed with percentage and the pearson productmoment correlation. The results showed that the achievement level consisiting of ) recognition,2) representation, 3) structural abstraction, and 4) structural awareness of the students' reflective abstraction abilities on linear algebra problem solving are very good, this can be seen from the percentage achieved at stages of the recognition,the representation,the structural abstraction, and the structural awareness which is associated with Polya problem solving measures above an average of 73,31\% (moderat category); there are relationship between students' reflective abstraction abilities and their prerequisite knowledge; and prerequisite knowledge influences the students'reflective abstraction abilities.
\end{abstract}

Copyright $($ C) 2021 IKIP Siliwangi. All rights reserved.

\section{Corresponding Author:}

Rahayu Kariadinata,

Mathematics Education Study Program,

Faculty of Tarbiyah and Teacher Training,

Universitas Islam Negeri Sunan Gunung Djati Bandung

Jl. A.H. Nasution No. 105A, Bandung, Jawa Barat 40294, Indonesia

Email: rahayu.kariadinata@uinsgd.ac.id

\section{How to Cite:}

Kariadinata, R. (2021). Students' reflective abstraction ability on linear algebra problem solving and relationship with prerequisite knowledge. Infinity, 10(1), 1-16.

\section{INTRODUCTION}

Linear Algebra is a compulsory subject that is presented at the Mathematics Education Study Program UIN Sunan Gunung Djati Bandung with the aim that students can master and be skilled in applying Linear Algebra concepts for solving problems in daily life, in various fields both in mathematics and science- other sciences through linear equation 
models, for example, in the field of information technology, Linear Algebra has become the foundation for algorithms, the application of vectors in the computer field is very clear in graphic design application programs, and in the economic and social fields through the matrix, Linear Algebra is also useful in terms of optimization. Linear algebra represents, with calculus, the two main mathematical subjects taught in science universities (Dorier, 2002) where linear algebra has been traditionally taught in a very theoretical way, this teaching tends now to be more orientated towards numerical computations, even if the structural approach remains important for the minority of students majoring in mathematics (Dorier \& Sierpinska, 2001). Linear Algebra is a field of mathematical study that studies systems of linear equations and solutions, special properties of vector spaces and lineari transformations (Kariadinata, 2019).

The importance of the role of Linear Algebra above, students should be able to understand the concept of Linear Algebra adequately so that good learning outcomes are obtained, but in reality, based on the experience of teaching Linear Algebra courses and interviews with a number of students, it was found that most of the students felt difficulties in solving Linear Algebra problems. This is due to a change in students' thinking from elementary mathematical thinking to advanced mathematical. On one level, students' difficulties with linear algebra stem simply from their inexperience with proofs and proofbased theories. Indeed, students' proofrelated difficulties (Hillel, 2000). Students are often taught procedurally how to find a basis for a subspace using matrix manipulation, but may struggle with understanding the construct of basis, making further progress harder (Stewart \& Thomas, 2010). Another fact is that mathematics education students tend to have a lack of confidence in communicating mathematical ideas, not being able to provide appropriate arguments in accordance with facts, principles and mathematical procedures, difficulties in proving theorems, reasons for fear of being wrong or not mastering the material properly the ability of symbol sense and student structure sense is still low because of a lack of conceptual knowledge and algebraic manipulation (Kariadinata et al., 2017; Sugilar et al., 2019).

Mathematics in higher education has characteristics towards a formal framework of axiomatic and verification systems, so students must have advanced mathematical thinking abilities. which is an ability that can train students to construct and create their own mathematical definition images. Advanced mathematical thinking includes the ability of representation, abstraction, creative thinking, and mathematical proof. The main factor that becomes a barrier for students is a lack of understanding of rules, definitions, procedures, and concepts that are very abstract. Panjaitan (2009) One of the characteristics of mathematics is to have abstract study objects, so that abstraction becomes an important part that cannot be separated from mathematics. In these conditions, students need the ability of abstraction which is an important part of learning mathematics. Abstraction is an activity which is a mental process in forming a mathematical concept that involves relationships between mathematical structures or objects (Wiryanto, 2014). The results of a study conducted by Tall (1994) conclude that mathematical concept abstractions basically use abstractions that focus on objects and abstractions that focus on object operations. Examples of abstractions that focus on objects are geometry, and examples of abstractions that focus on object operations are arithmetic and algebra.

Mitchelmore and White (2004) provide examples of abstract objects in mathematics in schools, for example on the topic rate of change in Calculus. The most basic idea in Calculus is the rate of change, leading to differential. This is a major reform movement in the last ten years related to meaningful ideas by initially exploring a series of rates of change to realistic situations. In this way students build intuitive ideas of rate of change before studying the topic abstractly. Mathematical objects are constructed through the formation of relationships in such a way that they find new generalizations, evidence, or strategies for 
problem solving (Schwarz et al., 2010). While, Tall (1994) argues that abstraction is the process of drawing certain situations into concepts. which can be thought of (thinkable concept) through a construction. These concepts that can be thought of can then be used at a more complicated and complex level of thinking.

There is a three-part theory of theory (tripartite theory) about abstraction proposed by Piaget (Gray \& Tall, 2007), namely: 1) empirical abstraction which focuses on the way students construct the meaning of objects, 2) pseudoempirical abstraction which focuses on the way students construct the meaning of the nature of the action on the object, 3) reflective abstraction that focuses on the idea of action and operations into thematic objects in thought or assimilation, which is related to the categorization of mental operations and abstraction of mental objects.

Reflective abstraction is an important mechanism that can explain how students build conceptual knowledge by giving reasons for decisions made (Goodson-Espy, 1998). Reflective abstraction activities have a level as stated by Cifarelli (1990), namely the first level is recognition, the second level is representation, the third level is structural abstraction, and the fourth level or the highest level is structural awareness. When students solve Linear Algebra problems, they must be aware of what is abstracted. Here it needs to be seen whether students are able to express or demonstrate their awareness of problem solving activities, and provide reasons for decisions or conclusions obtained in problem solving (Wiryanto, 2014).

Problem solving is as an attempt to find a way out of a difficulty, achieve a goal that is not easily achieved. The series of steps that students must take in solving mathematical problems as recommended by Polya (1973), namely: (1) understanding the problem (this includes): a) what is known? b) what was asked? c) is the condition of the problem given sufficient or incomplete to look for what was asked ?; (2) devising a plan, (planning for completion) this includes: a) what theories can be used in this problem? b) should other elements be sought in order to take advantage of the problem or state it in another form? (3) carrying out the plan (solving the problem) this includes: a) implementing the settlement by checking each step whether it is correct or not?, b). prove that the chosen step is correct; and (4) looking back in this section emphasizes how to check the answers that have been obtained.

The ability to solve the Linear Algebra problems associated with levels in reflective abstraction requires adequate prerequisite knowledge. This is because the characteristics of mathematical concepts that are hierarchical, meaning to be able to understand a particular concept must understand the previous concept. Based on the experience of researchers teaching Linear Algebra courses, students have difficulty in certain concepts that require prerequisite knowledge. Some concepts in linear algebra require prerequisite knowledge, namely in finding solutions to the set of systems of linear equations using elementary line operations. In the matter of linear independence, to prove whether a vector set is a set that is linear independence or linearly dependent, students must have knowledge of the homogeneous linear equations system and their solutions. The prerequisite knowledge has been given. Gagne and Briggs (Riyanto, 2014) state that in the learning process there is a very important component, namely learning-prerequite sequences which are interpreted as a sequence of learning prerequisites or learning hierarchy, so that the presentation of certain material will not be carried out if the material which is a prerequisite has not been presented. Some research results on prerequisite knowledge reveal that mastery of basic materials as a prerequisite in learning mathematics is still very low.

Research indicates that prior to learning algebra, students must have an understanding of numbers, ratios, proportions, the order of operations, equality, algebraic symbolism (including letter usage), algebraic equations and functions (Welder, 2006). 
Likewise, various theories state that the importance of prerequisite knowledge will be linked to new knowledge, including Ausubel et al., (1968) learning theory which is famous for meaningful learning. According to this theory, learning is said to be meaningful if the information students will learn is arranged in accordance with the cognitive structure (can be in the form of facts, concepts or generalizations that have been obtained or even understood beforehand by students) that students have so that students can associate information new with the cognitive structure it has. So in learning mathematics students must have prerequisite knowledge inherent in their minds. As stated by Nur (2000) that prior knowledge is a compulsory ability possessed by students in the learning process.

In this study the prerequisite knowledge that was studied was knowledge of the Matrix Algebra concept. Some concepts in linear algebra require knowledge of the concept of matrix algebra. As the results of previous research conducted Suryaningsih (2017), regarding the correlation of learning outcomes in Elementary Linear Algebra for students of the Mathematics Education Study Program, FKIP University of Lambung Mangkurat based on prerequisite subjects, conluded that there is a positive and significant correlation between learning outcomes in the matrix prerequisite course and learning outcomes for Elementary Linear Algebra. Other relevant research conducted Mufidah et al. (2019) conducted a study on the analysis of understanding the concept of algebra in the Elementary Linear Algebra course, concluding that the ability to understand students majoring in mathematics education at UIN Alauddin Makassar class of 2016 in solving elementary linear algebra problems in terms of ability indicators mathematical understanding, students are quite capable of indicators: (1) understanding is able to restate a concept, (2) presenting a concept in various forms of mathematical representation, (3) using, utilizing and selecting certain procedures, and (4) applying concepts / algorithms to problem solving. However, students are classified as incapable of the ability to give examples and not examples.

The difference between this study and the studies mentioned above is in the domain of thinking. Learning outcomes and understanding can be seen separately with the ability of reflective abstraction which is a useful tool for learning high-level mathematical thinking, which will give rise to a theoretical basis that supports and contributes to teachers' understanding of thinking and how teachers can help students improve their abilities. Reflective abstraction is a concept introduced by Piaget to explain the construction of a person's mathematical logic structure in cognitive development when studying a concept. The result of reflective abstraction is a schema (mental structure) of knowledge at each stage of development and reflective abstraction brings together a corresponding scheme of action patterns (Fuady \& Rahardjo, 2019).

Mastery of the concept of matrix algebra is one of the skills or skills expected to be achieved in Linear Algebra lectures through the ability of students to make connections between concepts, application of concepts and algorithms flexibly, accurately, efficiently, and precisely in problem solving. A study of the importance of learning algebra concludes that misunderstanding of concepts in algebra material will have an impact on other material and will certainly lead to learning difficulties that lead to low learning outcomes (Irfan \& Anzora, 2017). This study aims to analyze the ability of students' reflective abstraction on Linear Algebra problem solving in Basis material and the relation of prerequisite knowledge.

\section{METHOD}

This research is a descriptive study with a quantitative approach, which is a study that aims to explain a phenomenon by using meaningful numbers based on processing to draw conclusions. The method used in this research is the correlational method. The correlational method is one of the quantitative research methods based on the positivism 
philosophy which emphasizes objective phenomena and is studied quantitatively. This study will describe the ability of students' reflective abstraction in Linear Algebra problem solving and their relationship to prerequisite knowledge. The subjects of this study were 31 students in $3^{\text {th }}$ semester of 2019/2020 academic year who were taking Linear Algebra in the Mathematics Education Study Program, Faculty of Tarbiyah and Teacher Training of UIN Sunan Gunung Djati Bandung.

Data collection is done by providing Linear Algebra test on Basis material. The results of student work were analyzed and then interviews were conducted. This is to reveal the description of students' abilities about the concept of Basis through the levels of reflective abstraction according to Cifarelli (1990), namely the level of recognition, representation, structural abstraction and structural awareness and problem-solving abilities based on (Polya, 1973). The results of written and verbal answers (obtained during interviews) are then reviewed based on the reflective abstraction descriptor and problem solving.

The instruments used in this study were the Linear Algebra Problem Solving Test and interview guides. Respondents who were interviewed were as many as research subjects, namely 31 students, this was based on considerations in order to obtain data that could support quantitative data. The analysis in this study emphasizes the results of Linear Algebra written tests and interview results. To find out the level of achievement of the reflective abstraction ability of students in Linear Algebra problem solving, percentage analysis is used. The five levels of students' reflective abstraction ability attainment are presented in Table 1.

Table 1. Criteria for achievement of students' reflective abstraction ability as a percentage $(\%)$

\begin{tabular}{ccc}
\hline No & Level of Achievement & Category of Achievement \\
\hline 1 & $86-100 \%$ & Very high \\
2 & $74-85.99 \%$ & High \\
3 & $62-73.99 \%$ & Moderat \\
4 & $50-61.99 \%$ & Low \\
5 & $<49.99 \%$ & Very low \\
\hline
\end{tabular}

The relationship between variables in this study is illustrated as the following Figure 1.



Figure 1. Chart of research thinking framework

Whereas to determine the effect of the prerequisite ability on the reflective abstraction ability of students in solving linear algebra problems a product moment 
correlation test was used. Based on the definition of reflective abstraction and linear algebra problem solving for the basic concept, in this study descended descriptors as shown in Table 2.

Table 2. Problem solving descriptors based on polya and the level of reflective abstracts and their activities

\begin{tabular}{|c|c|c|}
\hline $\begin{array}{l}\text { Step of Problem } \\
\text { Solving } \\
\text { (Polya, 1973) }\end{array}$ & $\begin{array}{c}\text { Level of } \\
\text { Reflective } \\
\text { Abstraction } \\
\text { (Cifarelli, 1990) }\end{array}$ & Descriptor and Activities \\
\hline \multirow{4}{*}{$\begin{array}{l}\text { Understanding } \\
\text { the problem }\end{array}$} & Recognition & $\begin{array}{l}\text { Student read the problem given and organize the structure } \\
\text { that must be solved }\end{array}$ \\
\hline & Representation & $\begin{array}{l}\text { Student express the results of previous thoughts in the } \\
\text { form of words; translating and transforming information } \\
\text { or structure into mathematical models }\end{array}$ \\
\hline & $\begin{array}{l}\text { Structural } \\
\text { abstraction }\end{array}$ & $\begin{array}{l}\text { Student develop a new strategy for a problem, which has } \\
\text { not been used before and organizing the structure of } \\
\text { mathematical problems }\end{array}$ \\
\hline & $\begin{array}{r}\text { Structural } \\
\text { awareness }\end{array}$ & $\begin{array}{l}\text { Student give arguments or reasons correctly to the } \\
\text { decisions made and reflects the decision obtained for the } \\
\text { next activity. }\end{array}$ \\
\hline \multirow{3}{*}{ Devising a plan } & Recognition & $\begin{array}{l}\text { Student recall previous activities related to the problem to } \\
\text { be solved and identifying previous activities related to the } \\
\text { current problem }\end{array}$ \\
\hline & Representation & $\begin{array}{l}\text { Student express the results of previous thought in the form } \\
\text { of mathematical symbols, words, graphs to help } \\
\text { reconstruction; translating and transforming information } \\
\text { into mathematical models }\end{array}$ \\
\hline & $\begin{array}{l}\text { Structural } \\
\text { abstraction }\end{array}$ & $\begin{array}{l}\text { Student develop a new strategy for a problem and } \\
\text { organize the structure of mathematical problems such as } \\
\text { organizing, organizing and developing }\end{array}$ \\
\hline \multirow{4}{*}{$\begin{array}{l}\text { Carrying out the } \\
\text { plan }\end{array}$} & Recognition & $\begin{array}{l}\text { Students can use alternative solutions and develop other } \\
\text { strategies for problem solving }\end{array}$ \\
\hline & Representation & $\begin{array}{l}\text { Students can plan correctly, represent mathematical } \\
\text { models and solve problems. }\end{array}$ \\
\hline & $\begin{array}{l}\text { Structural } \\
\text { abstraction }\end{array}$ & $\begin{array}{l}\text { Students can develop a new strategy for a problem, which } \\
\text { has not been used before and reorganize the structure of } \\
\text { mathematical problems }\end{array}$ \\
\hline & $\begin{array}{l}\text { Structural } \\
\text { awareness }\end{array}$ & $\begin{array}{l}\text { Students can give arguments or reasons correctly to the } \\
\text { decisions made and summarize their activities correctly } \\
\text { during problem solving and connected in a structured way }\end{array}$ \\
\hline \multirow[b]{3}{*}{ Looking back } & Recognition & Students can identify or recall the results obtained \\
\hline & Representation & $\begin{array}{l}\text { Students can see the plan has made and represent } \\
\text { mathematical models to solve the problems }\end{array}$ \\
\hline & $\begin{array}{l}\text { Structural } \\
\text { abstraction }\end{array}$ & $\begin{array}{l}\text { Students can examine new strategies for a problem, which } \\
\text { had not been used before and examine the structure of } \\
\text { mathematical problems such as the preparation and } \\
\text { organization of a problem }\end{array}$ \\
\hline
\end{tabular}




\section{RESULTS AND DISCUSSION}

\subsection{Results}

The results of this study will describe the achievement of the students' reflective abstraction abilities on Linear Algebra problem solving obtained from test and interview results and the relationship between the reflective abstraction ability with prerequisite knowledge. Following is the Linear Algebra test, Basis material.

Let, $v_{1}=(2,1,-1), v_{2}=(-1,5,1)$ dan $v_{3}=(2,1,3)$. Find out whether the set $S=\left\{v_{1}, v_{2}, v_{3}\right\}$ is the basis for $R^{3}$ ?

The following summarizes the results of tests and interviews about the achievement of students' reflective abstraction ability on Linear Algebra problem solving, Basis material adjusted to Polya's problem solving steps (Polya, 1973) and the level of reflective abstraction from (Cifarelli, 1990).

In the step of Problem Solving Polya (1973) namely Understanding the problem on level of Reflection Abtraction Cifarelli (1990) namely Recognition, through interview $86.45 \%$ students understand the problem through reading and reorganize the structure of the problem by writing a basic definition that is write it : "If $V$ is any vector space and $S=\{$ $\left.v_{1}, v_{2}, \ldots ., v_{r}\right\}$ is a finite set of vectors in $V$, then $S$ is called a basis for $V$ if: $S$ is linearly independent and $S$ span $V$; level Representation, through interview and written test $30.22 \%$ and $78.89 \%$ student can identify existing vectors then connect with one of the statements of the theorem: " $S$ is a set with two or more vectors is linearly independent if and only if at least one of the vectors is a linear combination of the remaining vectors" ; level Structural abstraction, through interview and written test, $74.36 \%$ and $87.98 \%$ student understand that to prove $S$ basis for $V$, it must be filled that $S$ linearly independent and $S$ span $V$; level Structural awareness, through written test, $89.98 \%$ student can prove that $S$ is linearly independent and span $V$ can jointly prove it by showing that the coefficient matrix of a linear equations system that is formed from the description of linearly independent and stretching is a coefficient matrix, then the determinant value will be sought.

In the step of Problem Solving Polya (1973) namely Devising a plan on level of Reflection Abtraction Cifarelli (1990) namely Recognition through written test, 93.54\% students can write the term of form the equality of linearly independent and span $V:$ a) $k_{1} v_{1}$ $+k_{2} v_{2}+k_{3} v_{3}=\mathbf{0} \quad$ b) $z=k_{1} v_{1}+k_{2} v_{2}+k_{3} v_{3}$; level Representation through written test, $85.67 \%$ students can represent the form of equations from:

a) Linearly independent: $k_{1} \mathrm{v}_{1}+k_{2} \mathrm{v}_{2}+k_{3} \mathrm{v}_{3}=\mathbf{0}$

$$
\begin{aligned}
& \Leftrightarrow k_{1}(2,1,-1)+k_{2}(-1,5,1)+k_{3}(2,1,3)=(0,0,0) \\
& \Leftrightarrow\left(2 k_{1}, k_{1},-k_{1}\right)+\left(-k_{2}, 5 k_{2}, k_{2}\right)+\left(2 k_{3}, k_{3}, 3 k_{3}\right)=(0,0,0) \\
& \Leftrightarrow\left(2 k_{1}-k_{2}+2 k_{3}, k_{1}+5 k_{2}+k_{3},-k_{1}+k_{2}+3 k_{3}\right)=(0,0,0)
\end{aligned}
$$

b) Span $V: \mathrm{z}=k_{1} \mathrm{v}_{1}+k_{2} \mathrm{v}_{2}+k_{3} \mathrm{v}_{3}$

$$
\begin{aligned}
& \Leftrightarrow \quad\left(\mathrm{z} 1, \mathrm{z}_{2}, \mathrm{Z}_{3}\right)=k_{1}(2,1,-1)+k_{2}(-1,5,1)+k_{3}(2,1,3) \\
& \Leftrightarrow \quad\left(\mathrm{z}_{1}, \mathrm{z}_{2}, \mathrm{z}_{3}\right)=\left(2 k_{1}, k_{1},-k_{1}\right)+\left(-k_{2}, 5 k_{2}, k_{2}\right)+\left(2 k_{3}, k_{3}, 3 k_{3}\right) \\
& \Leftrightarrow \quad\left(\mathrm{z}_{1}, \mathrm{z}_{2}, \mathrm{z}_{3}\right)=\left(2 k_{1}-k_{2}+2 k_{3}, k_{1}+5 k_{2}+k_{3},-k_{1}+k_{2}+3 k_{3}\right)
\end{aligned}
$$

Level Structural abstraction through written test, $85.69 \%$ students can express a system that matches the equation: $k_{1} v_{1}+k_{2} v_{2}+k_{3} v_{3}=\mathbf{0}$

that is :

$\left.\begin{array}{l}2 k_{1}-k_{2}+2 k_{3}=0 \\ k_{1}+5 k_{2}+k_{3}=0 \\ -k_{1}+k_{2}+3 k_{3}=0\end{array}\right\} \ldots$ 
states the system that matches the equation: $z=k_{1} v_{1}+k_{2} v_{2}+k_{3} v_{3}$, that is

$\left.\begin{array}{c}2 k_{1}-k_{2}+2 k_{3}=z_{1} \\ k_{1}+5 k_{2}+k_{3}=z_{2} \\ -k_{1}+k_{2}+3 k_{3}=z_{3}\end{array}\right\} \ldots . .(* *)$

students can prove that $S$ is linearly independent and span $V$ simultaneously by showing that the coefficient matrix of the system $(*)$ and $(* *)$

In the step of Problem Solving Polya (1973) namely Carrying out the plan on level of Reflection Abtraction Cifarelli (1990) namely Recognition through interview, 81.20\% students can solve problems according to plan, use alternative solutions and develop other strategies to get a solution; level Representation through written test, $85.69 \%$ students can plan correctly and represent mathematical models and solve the problems. Representation of coefficient matrices of linear system form $(*)$ and $(* *)$

$$
A=\left[\begin{array}{rrr}
2 & -1 & 2 \\
1 & 5 & 1 \\
-1 & 1 & 3
\end{array}\right],
$$

Level Structural abstraction through written test, $75.69 \%$ students can develop new strategies for a problem, which before they have not used, reorganize the structure of mathematical problems in the form of organizing, organizing and developing, based on the formed coefficient matrix, students look for the determinant value, that is:

$$
\begin{aligned}
\operatorname{det}(\mathrm{A}) & =\left|\begin{array}{rrr}
2 & -1 & 2 \\
1 & 5 & 1 \\
-1 & 1 & 3
\end{array}\right| \\
& =44
\end{aligned}
$$

States the terms $S$ linearly independent and $S$ span $V$ are associated with the determinant value through the theorem which states:

"If $A$ is an $n \times n$ matrix, then the following statements are equivalent.

a) $A$ is invertible

b) $A X=0$ has only the trivial solution

c) $A$ is row equivalent to $I_{n}$

d) $A X=B$ is consistentfor every $\times x 1$ matrix $B$

Level Structural awareness through written test, $45.69 \%$, students can give arguments or reasons correctly to the decisions made, and are able to summarize their activities correctly during problem solving and connected in a structured way, can associate the determinant values obtained with the theorem above. The value of $\operatorname{det}(\mathrm{A})=44$, this value is not equal to zero $(\neq 0)$, then the matrix can be reversed, in a homogeneous linear equation system if the coefficient matrix has a determinant value $\neq 0$ then the system has a trivial solution, thus $S$ is linearly independent, so too because the system is consistent, there are values of $k_{1}, k_{2}$ and $k_{3}$, so $S$ spans $V$. Therefore, because both conditions have been fulfilled, $S$ is the Basis for $V$.

In the step of Problem Solving Polya (1973) namely Looking back on level of Reflection Abtraction Cifarelli (1990) namely Recognition through interview, 76.56\%, students can recall the results obtained: 1) the terms of linearly independent, the form of: $\mathrm{k}_{1} \mathrm{v}_{1}+\mathrm{k}_{2} \mathrm{v}_{2}+\mathrm{k}_{3} \mathrm{v}_{3}=\mathbf{0}$ have trivial solution, then: $\mathrm{k}_{1}=0, \mathrm{k}_{2}=0, \mathrm{k}_{3}=0 ; 2$ ) the terms of span $V$ : there are any vectors in $V$ for example $\mathrm{z}=\left(\mathrm{z}_{1}, \mathrm{z}_{2}, \mathrm{z}_{3}\right)$ can be expressed as a linear combination of $\mathrm{z}_{1}, \mathrm{z}_{2}$, $\mathrm{z}$; ; level Representation through interview, 63.76\% students have planned it correctly and look back at the form of mathematical models and problem solving. 
For linearly independent :

If $k_{1}=0, k_{2}=0$ and $k_{3}=0$ are substituted into the equation:

$\Leftrightarrow k_{1}(2,1,-1)+k_{2}(-1,5,1)+$

$k_{3}(2,1,3)=\mathbf{0}$

$\Leftrightarrow \quad 0(2,1,-1)+0(-1,5,1)+0(2,1,3)=(0,0,0)$

$\Leftrightarrow \quad(0,0,0)+(0,0,0)+(0,0,0)=(0,0,0)$

For span :

Based on the theorem that "A can be reversed and $\mathrm{AX}=\mathrm{B}$ is consistent for each matrix size $\mathrm{n} \times 1$ " so that there are values $\mathrm{k}_{1}, \mathrm{k}_{2}$ and $\mathrm{k}_{3}$ so that $\mathrm{z}=\left(\mathrm{z}_{1}, \mathrm{z}_{2}, \mathrm{z}_{3}\right)$ can be expressed as a linear combination of vectors $\mathrm{v}_{1}=(2.1,-1)$, $\mathrm{v}_{2}=(-1,5,1)$ and $\mathrm{v}_{3}=(2,1,3)$.

level Structural abstraction through interview, $34.31 \%$ students can complete the terms of linearly independent and span by reducing the equations $(*)$ and $(* *)$ one by one using elementary row operations to obtain a trivial solution, $\mathrm{k}_{1}=0, \mathrm{k}_{2}=0, \mathrm{k}_{3}=0$ and many solutions that are responsible (consistent) for values of $\mathrm{k}_{1}, \mathrm{k}_{2}, \mathrm{k}_{3}$ thus solving this Basis problem in a different way, students can reorganize the structure by looking back to the trivial solution from a homogeneous linear equation system, if $\mathrm{k}_{1}=0, \mathrm{k}_{2}=0, \mathrm{k}_{3}=0$ and if there are other solutions (non-trivial) then the conditions for linearly independent are not met, so too an $\mathrm{AX}=\mathrm{B}$ must be consistent, then the span requirements are met.

The following description of the results of research on the achievement of the students' reflective abstraction on Linear Algebra problem solving on the Basis material based on Polya's problem solving step (Polya, 1973) and the level of reflective abstraction (Cifarelli, 1990).

In the understanding of the problem (Polya) step at the recognition level of $86.45 \%$ students can reorganize the structure and can remember the requirements of a basis for $R^{3}$; at the representation level of $54.55 \%$ students can state the results of previous thinking in the form of words and relate the theorem to the completion of bases relating to linearly independent; at the structural abstaction level of $81.12 \%$ students can translate and transform information or structures into mathematical models; at the level of structural awareness of $89.98 \%$ of students can give arguments correctly to the decisions they make. This is supported by the results of the interview that students understand the problem through reading reorganize the structure of the problem by writing a basic definition.

In the devising a plan (Polya) step at the recognition level of $93.54 \%$ students can identify previous activities related to the problem to be solved; at the level of representation $85.67 \%$ of students can state the results of previous thinking in the form of mathematical symbols, words, graphics/form of equations to help reflection / reconstruction; at the structural abstaction level of $85.69 \%$ students can reorganize the structure of mathematical problems in the form of compiling, organizing and developing.

In the step of carrying out the plan (Polya) at the recognition level of $81.20 \%$ students can solve problems according to the plan and use and develop other strategies to get a solution; at the level of representation of $85.69 \%$ students have been able to represent in the form of mathematical models and solve the problem by writing the form of the coefficient matrix representation of the form of linear systems ; at the structural abstaction level of $75.69 \%$ students can develop new strategies for a problem, which have never been used before and reorganize the structure of mathematical problems in the form of compiling, organizing and developing, for example students can look for determinant values from the coefficient matrix that was written before, students can declare the requirements of $S$ linearly 
independent and $S$ span $V$ is associated with the determinant value through the theorem associated with it; at the level of structural awareness of $45.69 \%$ students can provide arguments or reasons correctly for the decisions made, and be able to summarize their activities correctly during problem solving and linked structurally, for example by knowing the determinant value is not equal to zero $(\neq 0)$, students can relate to solving a homogeneous linear equation system, which has a trivial solution, so that $S$ is linearly independent, so also because the system is consistent, then there are values $k_{1}, k_{2}$ and $k_{3}$, so $S$ spans $V$.

In the looking back step (Polya) at the recognition level of $76.56 \%$ students can identify or recall the results obtained, namely about the basic requirements namely $S$ linearly independent and $S$ span $V$; at the representation level of $63.76 \%$ students have examined the form of mathematical representation and examined its completion; at the structural abstaction level of $34.31 \%$ students can check the strategies used for a problem, namely strategies that simultaneously prove that $S$ is linearly free and span $R^{3}$ by showing the efficiency matrix is not equal to zero $(\neq 0)$ based on the theorem related to it.

Based on the description above, in summary the average percentage of students' ability to achieve reflective abstraction in solving Linear Algebra problems in Base material can be seen in Table 3 .

Table 3. Average persentage of the students' achievement of reflective abstraction ability on linear algebra on basis material

\begin{tabular}{llcc}
\hline $\begin{array}{c}\text { Step of } \\
\text { Problem Solving } \\
\text { (Polya, 1973) }\end{array}$ & \multicolumn{1}{c}{$\begin{array}{c}\text { Level of Reflective } \\
\text { Abstraction } \\
\text { Cifarelli (1990) }\end{array}$} & Persentage & $\begin{array}{c}\text { Average } \\
\text { Persentage }\end{array}$ \\
\hline Understanding the & Recognition & 86.45 & 74.65 \\
problem & Representation & 1) 30.22 & \\
& Structural abstraction & 2) 78.89 & \\
& 1) 87.98 & \\
& Structural awareness & 2) 74.36 & \\
\hline Devising a plan & Recognition & 89.89 & \\
& Representation & 93.54 & \\
& Structural abstraction & 85.67 & \\
\hline Carrying out the & Recognition & 85.69 & \\
plan & Representation & 85.20 & \\
& Structural abstraction & 75.69 & \\
& Structural awareness & 45.69 & \\
\hline Looking back & Recognition & 76.56 & \\
& Representation & 63.76 & 73.31 \\
& Structural abstraction & 34.31 & \\
\hline
\end{tabular}

Based on Table 3, it can be seen that the average percentage of students' reflective abstraction achievement on Linear Algebra problem solving in Basis material is $73.31 \%$, this is categorized as moderate. Furthermore, the results of the descriptive statistical analysis are shown in Table 4. 
Infinitity Volume 10, No 1, February 2021, pp. 1-16

Tabel 4. Descriptive statistics

\begin{tabular}{cccccc}
\hline & N & Minimum & Maximum & Mean & $\begin{array}{c}\text { Std. } \\
\text { Deviation }\end{array}$ \\
\hline Reflective Abstraction Ability & 31 & 56 & 92 & 73.42 & 9.626 \\
Prerequisite Knowledge & 31 & 60 & 92 & 75.81 & 8.550 \\
\hline
\end{tabular}

Based on Table 4 it can be seen that the average value of reflective abstration ability is 73.42 and the average value of prerequisite knowledge is 75.81 . While the minimum value of reflective abstraction ability is 56 and for prerequisite knowledge is 60, while the maximum value of the two variables is the same, namely 92 . Furthermore, product moment correlation analysis is performed to see the relationship between the students' reflective abstraction on Linear Algebra problem solving with prerequisite knowledge, the results of the analysis are shown in Table 5.

Table 5. Correlations

\begin{tabular}{cccc}
\hline & & $\begin{array}{c}\text { Prerequisite } \\
\text { Knowledge }\end{array}$ & $\begin{array}{c}\text { Reflective } \\
\text { Abstraction } \\
\text { Ability }\end{array}$ \\
\hline Reflective & Pearson Correlation & $0.688^{* *}$ & 1 \\
Abstraction Ability & Sig. (2-tailed) & 0.000 & 31 \\
\hline Prerequisite & N & 31 & $0.688^{* *}$ \\
Knowledge & Pearson Correlation & 1 & 0.000 \\
& Sig. (2-tailed) & & 31 \\
\hline
\end{tabular}

To examine the relationship between the students' reflective abstraction on Linear Algebra problem solving with prerequisite knowledge, the following hypotheses are first made:

$\mathrm{H}_{0}=$ There is no relationship between the students' reflective abstraction on Linear Algebra problem solving with prerequisite knowledge

$\mathrm{H}_{1}=$ There is a relationship between the students' reflective abstraction on Linear Algebra problem solving with prerequisite knowledge

Decision:

In the Asymp column. Sig $=0,000$ this value is smaller than 0.05 then $\mathrm{H}_{0}$ is rejected and $\mathrm{H}_{1}$ is accepted, so it is concluded that there is a relationship between the students' reflective abstraction on Linear Algebra problem solving with prerequisite knowledge. The magnitude of the correlation coefficient (relationship) is $r=+0.688$, this shows a positive relationship between the students' reflective abstraction on Linear Algebra problem solving with prerequisite knowledge and when viewed from the Pearson correlation classification, then this value is in the range $0.60-0.799$, i.e. strong category, so it can be concluded that there is a strong relationship between the students' reflective abstraction on Linear Algebra problem solving with prerequisite knowledge.

Furthermore, to see how much the relationship between the students' reflective abstraction on Linear Algebra problem solving with prerequisite knowledge, the coefficient of determination will be sought namely: $\mathrm{D}=(\mathrm{r})^{2}=(+0.688)^{2}=0.47344$ or $47.34 \%$. This shows that $47.34 \%$ of the students' reflective abstraction on Linear Algebra problem solving 
are influenced by their prerequisite knowledge, namely students' Algebra Matrix knowledge. While the remaining 52,66\% is influenced by other factors not examined in this study.

\subsection{Discussion}

Based on the results of research on the percentage of the students' achievement of reflective abstraction ability on Linear Algebra on Basis material at each Polya step (Polya, 1973) and the level of reflective abstraction from Cifarelli (1990), the overall average was $73.31 \%$ (medium category), but on several aspects produced a variety of average presentations including some above $73.31 \%$ and some below $73.31 \%$, for example, in the step of understanding the problem (Polya) on representation level, only $30.22 \%$ of students who could construct the results of his thinking in the form of words.

Based on the results of interviews at the understanding the problem stage, as many as $86.45 \%$ students understand the problem through reading, and reorganize the structure of the problem by writing a basic definition, This shows that students understand the problems given. This relates to student learning experiences, especially in solving various problems, it requires adequate experience and learning environment among students, as the opinion of (Dick et al., 2006) states that a student's task is to create a learning environment that is often termed "scenario problems" which reflects the existence of authentic or real learning experiences and can be applied in a situation.

In the step of devising a plan (Polya) at all levels of reflective abstraction, students show very good abilities. This can be seen from the average percentage of $88.30 \%$, including students who can translate and transform information or structures into mathematical models and run alternative possible solution methods, and develop new strategies for a problem. This is supported by the results of the interview that students can solve problems according to plan, use alternative solutions and develop other strategies to get a solution. This indicates that students have been able to make an external representative related to the problem formula. In the transition from mathematical models to mathematical results students use their mathematical abilities. This is the fifth stage of the modeling stage (Ferri, 2006).

In the step of carrying out the plan (Polya) at all levels, the students' reflective abstraction show good ability, this can be seen from the average percentage of $72.07 \%$, including students who have been able to solve problems according to plan, use alternatives and develop other strategies to get a solution. Thus, students have been able to structure the logic in cognitive development. It can be said that students already have the ability of reflective abstraction, as stated by Piaget reflective abstraction is a concept to explain the structure of one's mathematical logic in cognitive development when learning a concept (Gray \& Tall, 2007).

But in the looking back (Polya) step, the average percentage at the level of reflective abstraction of students showed a low ability, this can be seen from the average percentage of $58.21 \%$. Based on the results of the interview most of the students could not develop a new strategy for a problem, which had not been used before $(34.31 \%)$ and almost the majority of students did not carefully re-analyze every step of the completion that had been done. This is understandable because according to them they spend time when a careful reexamination of the results have been obtained. Whereas the benefits obtained by looking back at what has been done, according Polya (1985) that many benefits are obtained by taking the time to re-examine the work that has been done. Doing this according to Polya allows students to predict appropriate strategies that can be used to solve problems in the future. The things that are needed in the looking back step, namely: a) can students check the results?; b) can students check the argument ?; c) can students get different solutions?; d) can students see at a glance?; e) can students use the results or methods for some of these 
problems?. Thus, it is clear that to solve the problems, students need the reflective abstraction ability, as Goodson-Espy argues (Fuady \& Rahardjo, 2019) which says that the results of students' reflective mental abstraction are schemes used to understand things, find solutions, or solve problems.

Furthermore, in Linear Algebra problem solving on the Basis material, students connect from a problem solving activity to the next problem solving, for example, in proving whether a vector set $S=\left\{v_{1}, v_{2}, \ldots, v_{n}\right\}$ is the basis for $R_{n}$, students at least have to understand the Basis requirements, then he will explore various problem solving activities about linearly independent and continue with problem solving activities about span of vector, but students who are creative and critical will solve them together proving that $S$ is linearly independent and $S$ span $R_{n}$ by showing the coefficient matrix of the two can be reversed (has an inverse) It is clear here that many students involve and connect problem solving activities, as Piaget's opinion states that reflective abstraction is very important for higher mathematical logic thinking as occurs in logical thinking in students, students are able to solve new problems by using certain coordination of structures that have been built and reorganized (Tall, 1991).

Furthermore, the students' achievement of reflective abstraction ability on Linear Algebra on Basis material that is inseparable from the prerequisite knowledge, namely Matrix Algebra in the material Linear Equation System and Homogeneous Linear Equation System. The understanding ability of the completion with the Homogeneous Linear Equation System will relate to the material Linearly Independent which is one of the requirements of a Basis.

Based on the research results obtained that there is a positive relationship between the students' reflective abstraction on Linear Algebra problem solving with prerequisite knowledge, and the magnitude of the effect of prerequisite knowledge is $47.34 \%$ or in other words by $47.34 \%$ achievement of the students' reflective abstraction on Linear Algebra problem solving on Basis material is influenced by its prerequisite knowledge.

Mastery of prerequisite knowledge is very important because it shows the readiness of students to take the next material lesson. Advanced concepts are difficult to understand before understanding the previous concepts which are prerequisites. As according to understanding constructivism states that knowledge will be arranged or built up in the minds of students themselves as he seeks to organize his new experiences based on the cognitive framework that is already in his mind. Bodner (1986) states, "knowledge is constructed as the learner strives to organize his or her experience in terms of pre-existing mental structures". Thus, knowledge cannot be transferred from the teacher's brain to the student's brain.

Ausubel's meaningful learning theory states that meaningful learning will occur if students can associate new knowledge about a problem solving process that can be linked to prerequisite knowledge that students have learned. So according to Ausubel's theory of meaningful learning a very important factor according to him is old knowledge where new knowledge will adjust. He suggested a meaningful learning that is a learning process where new knowledge or experience can be related to old knowledge (prerequisite knowledge) that is already mastered by students, or in other words, meaningful learning will only occur if there is other knowledge in the student's mind (cognitive structure) such that new experiences can be related to it.

\section{CONCLUSION}

Based on the results obtained as follows that the percentage of the students' achievement of reflective abstraction ability on Linear Algebra problem solving in Basis material at : 1) the step of to the understanding the problem (Polya) at each level of reflective 
abstraction is a high category; 2) the steps of to the devising a plan (Polya) at each level of reflective abstraction of the high category; 3 ) the steps of the carrying out the plan (Polya) at each level of the reflective abstraction of the moderat category ; 4) the steps of the looking back (Polya) at each level of reflective abstraction are in the low category, but overall the percentage of the students' achievement of reflective abstraction ability at the problem solving step (Polya) at each level of the reflective abstraction are the moderate category; 5) there is a positive relationship between prerequisite knowledge and students 'reflection abstration abilities, this indicates that the prerequisite knowledge influences the students' reflection abstraction ability and is important in learning mathematics.

Based on the conclusions above, it is recommended that lecturers who teach Algebra group courses always check students' prerequisite knowledge before teaching a material. This can be done by giving a prerequisite knowledge test or by looking at the grades that have been achieved on the material that is a prerequisite. The ability of reflective abstraction must continue to be developed among students so that they can focus more on ideas about actions and operations which are thematic objects of thought or assimilation, which are related to the categorization of mental operations and abstraction of mental objects.

\section{ACKNOWLEDGMENTS}

The author would like to thank for the support to the Dean and Vice Deans, Chair of the Department of Mathematics and Natural Sciences (MIPA) and Chair of the Mathematics Education Study Program, Faculty of Tarbiyah and Teacher Training, UIN Sunan Gunung Djati Bandung, that has been support my research.

\section{REFERENCES}

Ausubel, D. P., Novak, J. D., \& Hanesian, H. (1968). Educational psychology: A cognitive view. Holt, Rinehart and Winston.

Bodner, G. M. (1986). Constructivism: A theory of knowledge. Journal of Chemical Education, 63(10), 873. https://doi.org/10.1021/ed063p873

Cifarelli, V. V. (1990). The role of abstraction as a learning process in mathematical problem-solving. Purdue University.

Dick, W., Carey, L., \& Carey, J. (2006). The systematic design of instruction (6th Editio). Allyn and Bacon.

Dorier, J. L. (2002). Teaching linear algebra at university. Proceedings of the International Congress of Mathematicians, August 20-28, 2002, 1, 875-884.

Dorier, J. L., \& Sierpinska, A. (2001). Research into the teaching and learning of linear algebra. In The teaching and learning of mathematics at university level (pp. 255273). Springer. https://doi.org/10.1007/0-306-47231-7_24

Ferri, R. B. (2006). Theoretical and empirical differentiations of phases in the modelling process. ZDM, 38(2), 86-95. https://doi.org/10.1007/BF02655883

Fuady, A., \& Rahardjo, S. (2019). Abstraction reflective student in problem solving of Mathematics based cognitive style. International Journal of Humanities and Innovation (IJHI), 2(4), 103-107. https://doi.org/10.33750/ijhi.v2i4.50 
Goodson-Espy, T. (1998). The roles of reification and reflective abstraction in the development of abstract thought: Transitions from arithmetic to algebra. Educational Studies in Mathematics, 36(3), 219-245. https://doi.org/10.1023/A:1003473509628

Gray, E., \& Tall, D. (2007). Abstraction as a natural process of mental compression. Mathematics Education Research Journal, 19(2), 23-40. https://doi.org/10.1007/BF03217454

Hillel, J. (2000). Modes of description and the problem of representation in linear algebra. In On the teaching of linear algebra (pp. 191-207). Springer. https://doi.org/10.1007/0-306-47224-4_7

Irfan, A., \& Anzora, A. (2017). Analisis Pemahaman Konsep Aljabar Mahasiswa Calon Guru melalui Peta Konsep pada Program Studi Pendidikan Matematika Universitas Abulyatama Aceh. Jurnal Dedikasi Pendidikan, 1(1), 1-10.

Kariadinata, R. (2019). Pengantar Aljabar Linear disertai Peta Konsep. Pustaka Setia.

Kariadinata, R., Sugilar, H., Farlina, E., \& Kurahman, O. T. (2017). The Sociomathematical Norms in Linear Algebra Lecture.

Mitchelmore, M., \& White, P. (2004). Abstraction in Mathematics and Mathematics Learning. International Group for the Psychology of Mathematics Education.

Mufidah, A., Sulasteri, S., Majid, A. F., \& Mattoliang, L. A. (2019). Analisis Pemahaman Konsep Aljabar pada Mata Kuliah Aljabar Linear Elementer. Al Asma: Journal of Islamic Education, 1(1), 42-52.

Nur, M. (2000). Strategi-strategi belajar. Universitas Negeri Surabaya.

Panjaitan, B. (2009). Level-Level Abstraksi Reflektif dalam Pemecahan Masalah Matematika. http://repository.uhn.ac.id/handle/123456789/410

Polya, G. (1973). How to solve it second edition. Princeton University Press.

Polya, G. (1985). How to Solve it a New Aspect of Mathematical Method (United State of America. Pricenton University Press.

Riyanto, H. Y. (2014). Paradigma Baru pembelajaran: Sebagai referensi bagi pendidik dalam Implementasi Pembelajaran yang Efektif dan berkualitas. Prenada Media.

Schwarz, B. B., Hershkowitz, R., \& Prusak, N. (2010). Argumentation and mathematics. Educational Dialogues: Understanding and Promoting Productive Interaction, 115, 141.

Stewart, S., \& Thomas, M. O. (2010). Student learning of basis, span and linear independence in linear algebra. International Journal of Mathematical Education in Science and Technology, 41(2), 173-188. https://doi.org/10.1080/00207390903399620

Sugilar, H., Kariadinata, R., \& Sobarningsih, N. (2019). Spektrum Symbol dan Structure Sense Matematika Siswa Madrasah Tsanawiyah. Kalamatika: Jurnal Pendidikan Matematika, $4(1)$, $37-48$. https://doi.org/10.22236/KALAMATIKA.vol4no1.2019pp37-48

Suryaningsih, Y. (2017). Korelasi Hasil Belajar Mata Kuliah Aljabar Linear Elementer Mahasiswa Program Studi Pendidikan Matematika FKIP Universitas Lambung Mangkurat Berdasarkan Mata Kuliah Prasyarat. EDU-MAT: Jurnal Pendidikan Matematika, 4(2), 118-125. https://doi.org/10.20527/edumat.v4i2.2569 
Tall, D. (1991). Advanced mathematical thinking (Vol. 11). Springer Science \& Business Media.

Tall, D. (1994). A versatile theory of visualisation and symbolisation in mathematics. Invited plenary lecture at the CIAEM Conference, 1, 15-26.

Welder, R. M. (2006). Prerequisite knowledge for the learning of algebra. Conference on Statistics, Mathematics and Related Fields, Honolulu, Hawaii, 1-26.

Wiryanto, W. (2014). Level-level Abstraksi Dalam Pemecahan Masalah Matematika. Jurnal Pendidikan Teknik Elektro, 3(3), 569-578. 